Article

\title{
High-Temperature Mineral Phases Generated in Natural Clinkers by Spontaneous Combustion of Coal
}

\author{
Elisa Laita *, Blanca Bauluz $@$ and Alfonso Yuste \\ IUCA-Facultad de Ciencias, Universidad de Zaragoza, Pedro Cerbuna 12, 50009 Zaragoza, Spain; \\ bauluz@unizar.es (B.B.); alfon@unizar.es (A.Y.) \\ * Correspondence: laita@unizar.es; Tel.: +34-627-675-602
}

Received: 4 March 2019; Accepted: 29 March 2019; Published: 1 April 2019

check for updates

\begin{abstract}
The aim of this study is to analyze natural clinkers (= calcined clays by coal combustion) from a lower Cretaceous coal outcrop in Ariño (Teruel, NE Spain) in order to describe mineral and textural transformations produced during the spontaneous combustion of coal. To achieve this aim, samples were analyzed using X-ray diffraction and optical and electron microscopy. Spontaneous combustion resulted in the melting of the surrounding clays, with the generation of an Al-Si-rich vitreous phase. Subsequently, high-temperature phases crystallized from this vitreous phase. These new minerals are interesting due to their similarity with those formed during ceramic processes, used in the manufacture of stoneware and ceramic tiles, as well as in refractory ceramics, and with natural events such as metamorphic and igneous processes. The studied natural clinkers are composed of vitreous phase mullite, hematite, hercynite, cristobalite, quartz, pyroxenes, cordierite, gypsum, pyrite, and calcium oxides. A trend from hematite to hercynite composition indicates compositional variations at sample scale, which evidence d-spacing differences in hercynite and may be related to the $\mathrm{Al}$ and Fe content in hercynite depending on its texture. The mullite shows higher $\mathrm{Si} / \mathrm{Al}$ ratio (1.21) than the theoretical composition (0.35), indicating that this mullite is more Si-rich. Three pyroxene-type compositions (diopside-type, ferrosilite-type, and a Ca-Al-rich pyroxene) were found. Both the mullite and the pyroxenes are nonstoichiometric.
\end{abstract}

Keywords: natural clinkers; coal spontaneous combustion; electron microscopy; high-temperature mineral transformations

\section{Introduction}

Spontaneous coal combustion is a frequent phenomenon that can take place in coal deposits when high quantities of these materials are stored for large periods [1,2]. Several researchers have described this process [3-9]. Spontaneous combustion occurs in coal seams, stockpiles, and coal wastes when the rate of heat generation from the oxidation of organic matter exceeds the rate of heat dissipation [3]. However, other factors could also favor or hinder spontaneous combustion [4]. According to these authors, heat from the oxidation of inorganic coal-bearing phases, such as pyrite, could be the key factor in attaining the necessary heat for the self-ignition of coal. Furthermore, several parameters influence the process of spontaneous heating and combustion in coal. These parameters relate to mining (panel dimension, ratio of coal, extraction, etc.), the geological parameters (faults, joints, etc.), and the coal chemical composition [10].

When the spontaneous combustion of coal takes places, new mineral phases are generated from those present in the previous coal and surrounding materials, i.e., clays, producing natural clinkers. The occurrence of natural clinkers associated with coal deposits has frequently been described in some areas [11-17]. 
The province of Teruel (NE, Spain) has historically been an important coal mining area, and there are still abundant coal deposits that can generate spontaneous combustion. Previous researchers have described the occurrence of natural clinkers in this area, and identified by means of X-ray diffraction a new mineral association generated by this spontaneous combustion $[18,19]$. However, there are no recent studies using high-resolution techniques in this area.

Accordingly, the aim of the present research is to study natural clinker samples from the locality of Ariño (Teruel, Spain) in order to describe the mineral and textural transformations that take place during the spontaneous firing of the coal, emphasizing in the mineral chemistry of the high-temperature phases in order to understand the calcination process. To this end, $\mathrm{X}$-ray diffraction (XRD) and optical and field-emission scanning electron microscopy (FESEM) were used.

The calcination process can be compared to ceramic processes since the new mineral phases generated are very similar [18-20]. Mineral phases such as mullite or pyroxenes have previously been described in ceramic materials in the literature [20-22]. These materials could thus be used in the manufacture of stoneware and ceramic floor, as well as in refractory ceramics. Some of these new phases are also reported in natural processes such as metamorphism $[14,23,24]$ and igneous processes [25-27]. For this reason, determining the chemical and textural characteristics of all the new phases may shed light on the characteristics of the spontaneous combustion of coal as well as on the differences between this natural process and other natural or ceramic processes.

\section{Geological Setting}

The samples analyzed in this study were taken from a coal mining area in the Iberian Range, NE Spain, in a natural outcrop near the coal mine of Santa Maria, close to the locality of Ariño (Teruel) (N 41 $01^{\prime} 53.28^{\prime \prime}$ W $0^{\circ} 34^{\prime} 50.24^{\prime \prime}$, elevation $539 \mathrm{~m}$ ).

The studied materials belong to the lower-middle Albian (Lower Cretaceous) sedimentary deposits of the Escucha Formation [28], which consists of three members: lower, middle, and upper. The lower member consists of marls at the bottom and carbonaceous clays with lignite beds towards the top. Carbonaceous clays with lignite remains and sandstones form the middle member, and the upper member is formed by limestones and sandstones [29].

This formation constitutes a depositional sequence that represents a freshwater swamp with brackish swamp plain areas. This environment allowed the accumulation and preservation of coal deposits, which can be found in the lower and middle members of the formation [28,30,31].

Near Ariño, the Escucha Formation is $200 \mathrm{~m}$ thick and contains abundant dark claystones and siltstones with minor sandstones [32]. Previous researchers have described several stratiform natural clinker levels in a nearby area, which are similar to that studied in this research. The natural clinkers are included in the coal seams [18].

The natural clinkers analyzed in this study present a scoriaceous appearance, with light and versicolor tones; they include clay and carbonaceous levels. The arrangement of the natural clinkers is stratiform and they are located from above and under the original position of the coal levels whose spontaneous combustion produced the calcination.

\section{Materials and Methods}

\subsection{Description of the Samples}

Precursor clays show plastic behavior and contain abundant organic matter, kaolinite, and illite, and minor proportions of quartz, $\mathrm{K}$ feldspar, siderite, pyrite, and Ti and Fe oxides [32]. They can be classified as ball clays and are mined nowadays.

Four representative samples of natural clinkers were studied on the basis of their different macroscopic characteristics and labeled as ESC-1, ESC-2, ESC-3, and ESC-4. All the samples are versicolor, with a vitreous appearance and high porosity. The size of the pores varies from 1 to $5 \mathrm{~mm}$ and they have irregular morphologies. 
Although they are heterogeneous in color, samples ESC-1 and ESC-4 are mainly red with black areas (which are more abundant in sample ESC-4), and samples ESC-2 and ESC-3 are mainly black with some yellow areas (Figure 1).

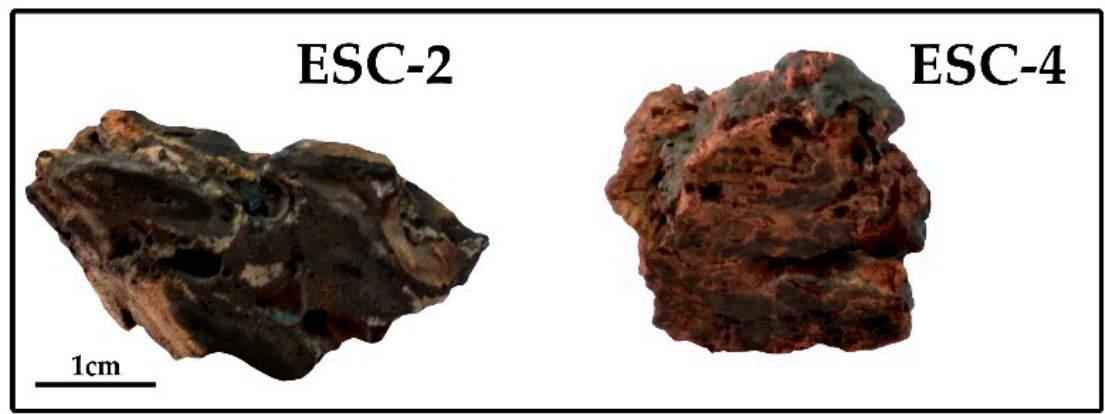

Figure 1. Images of a black natural clinker sample with yellow areas (ESC-2) and another red with black areas (ESC-4).

\subsection{X-ray Diffraction}

Mineralogical analyses of the samples were performed by X-ray diffraction (XRD). Sample ESC-2 was divided into two subsamples: ESC-2B, corresponding to the black zones, and ESC-2BY, which includes black and yellow areas. Similarly, ESC-3 was divided into ESC-3B, predominantly black, and ESC-3YB, including black and yellow zones. As a result, six XRD patterns were obtained: two XRD patterns correspond to whole samples ESC- 1 and ESC-4, and the other four patterns to samples ESC-2 and ESC-3.

To obtain the diffraction patterns, a RIGAKU D-Max/2500 diffractometer (Rigaku, Tokyo, Japan) was used with $40 \mathrm{kV}$ voltage, $80 \mathrm{~mA}$ current, $\mathrm{CuK} \alpha$, and a graphite monochromator. XRD patterns were obtained from the $3-80^{\circ} 2 \theta$ interval with a goniometer velocity of $0.03^{\circ} 2 \theta / \mathrm{s}$ and an integration time of $0.5 \mathrm{~s}$.

Once the XRD patterns were obtained, $d_{(400)}$ values of hercynite and $d_{(104)}$ values of hematite were determined using the quartz of the sample as an internal standard. The objective was to infer whether there was any relation between these parameters and the chemical composition of the phases. Hematite- and/or hercynite-rich samples (ESC-2B, ESC-2BY, ESC-3B, and ESC-3BY) were selected for this measure.

In order to quantify the different minerals, samples were homogenously mixed with $10 \mathrm{wt} \%$ corundum and analyzed by XRD, following the RIR cor method [33]. The amount $(\mathrm{X})$ of each component (i) in a mixed sample with corundum can be obtained with the formula $X_{i}=$ $\left[X_{\mathrm{cor}} / R I R_{\mathrm{cor}}\right]\left[I_{(\mathrm{hkl)i}} / I_{(113) \mathrm{cor}}\right]$, where $X_{\mathrm{cor}}$ is the percentage of corundum mixed with the test sample, $R I R_{\text {cor }}$ is the Reference Intensity Ratio of each phase with respect to corundum, $I_{(\mathrm{hkl})}$ is the absolute intensity of the strongest reflection of each mineral phase, and $I_{(113) \text { cor }}$ is the intensity of the (113) peak (2.08 $\AA$ ) of corundum.

$R I R_{\text {cor }}$ values of cristobalite (2.66) and gypsum (0.28) were calculated following the procedure described by [33]. The RIR cor of hematite (1.587), mullite (0.5660), quartz (4.4045), cordierite (0.91), and hercynite (3.03) were taken from the literature [20,34,35]. The reflections $(h k l)$ used for the quantification of each mineral were $2.69 \AA$ for hematite, $3.38 \AA$ for mullite, $3.34 \AA$ for quartz, $4.05 \AA$ for cristobalite, $8.56 \AA$ for cordierite, $2.45 \AA$ for hercynite, and $7.64 \AA$ for gypsum.

\subsection{Optical and Electron Microscopy Studies}

Thin sections of the natural clinkers were studied by transmitted and reflected light microscopy to identify mineral phases and characterize their texture. The same thin sections were analyzed by a Carl Zeiss Merlin field-emission scanning electron microscope (FESEM) with an Oxford energy-dispersive 
X-ray (EDS) detector at the University of Zaragoza (Zaragoza, Spain). The thin sections had previously been carbon-coated.

Compositional images of the samples were obtained using two types of backscattered electron detectors: angular selective (AsB) and energy selective (EsB). To obtain chemical information, semiquantitative analyses were acquired by an energy-dispersive X-ray (EDS) detector, with a detection limit of $0.1 \%$. The accelerating voltage for AsB and EDS was $15 \mathrm{kV}$ with a beam current of $400 \mathrm{pA}$; for $\mathrm{EsB}$, the accelerating voltage was $4 \mathrm{kV}$ with a beam current of $2.0 \mathrm{nA}$. Mineral formulas were obtained for the analyzed minerals in order to compare them with the theoretical compositions.

\section{Results}

\subsection{X-ray Diffraction (XRD): Qualitative Analysis and Mineral Quantification}

Samples ESC-1 and ESC-4 contain mullite, cristobalite, hematite, quartz, pyroxenes, and cordierite (Figure 2). The detected pyroxene reflections are common to several clynopyroxenes, so it is not possible to distinguish the type of pyroxene present in the natural clinkers on the basis of the XRD patterns. The coincidence of the characteristic peaks of tridymite with those of cristobalite and quartz does not allow its presence to be deduced, but it cannot be ruled out either.

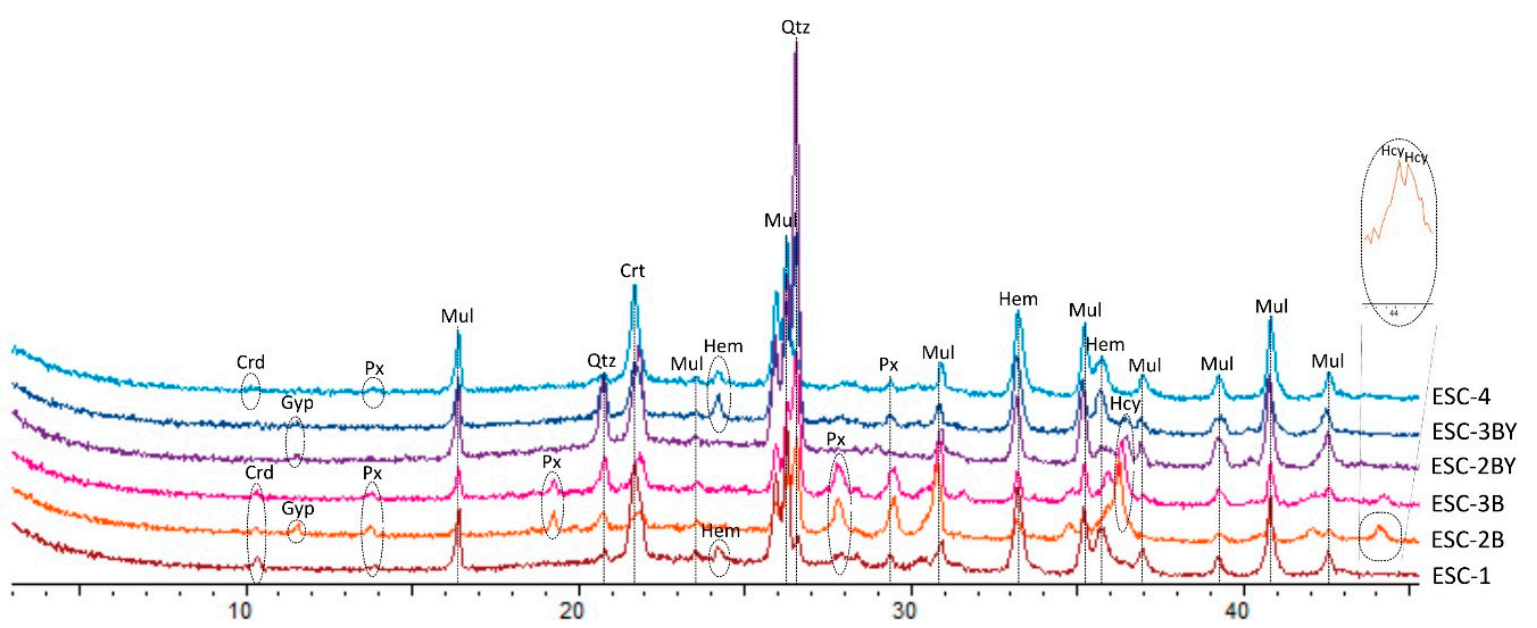

Figure 2. Mineral phases identified by XRD in the studied samples. Qtz = quartz, Hem = hematite, $\mathrm{Mul}=$ mullite, $\mathrm{Crt}=$ cristobalite, $\mathrm{Hcy}=$ hercynite $\mathrm{Px}=$ pyroxene, $\mathrm{Crd}=$ cordierite, $\mathrm{Gyp}=$ gypsum .

Subsamples ESC-2B, ESC-2BY, ESC-3B, and ESC-3BY contain mullite, cristobalite, hematite, hercynite, quartz, and pyroxenes as detected in ESC-1 and ESC-4. Cordierite was identified in subsamples ESC-2B and ESC-3B and gypsum was identified in XRD patterns in ESC-2B, ESC-2BY, and ESC-3BY.

The hercynite $d_{(400)}$ values show differences from sample to sample. Two different $d_{(400)}$ peaks are observed in subsample ESC-2B (Figure 2), corresponding to $d_{(400)}$ values of $8.208 \AA$ and $8.196 \AA$, and we infer that these values pertain to two different reflections corresponding to the (400) planes. In subsample ESC-3B the $d_{(400)}$ value for hercynite is $8.168 \AA$. The hematite $d_{(104)}$ values are similar in all the subsamples, with values of $2.693 \AA$, $2.695 \AA, 2.693 \AA$, and $2.693 \AA$ for subsamples ESC-2B, ESC-2BY, ESC-3B, and ESC-3BY, respectively.

According to quantitative XRD analyses (Table 1), mullite is the most abundant mineral, ranging from $16.3 \%$ to $38 \%$ of the total. The hercynite content is higher $(>4 \%)$ in samples ESC-2B and ESC-3B and the hematite content is higher $(\sim 10 \%)$ in samples ESC-3BY and ESC-4. ESC-2BY and ESC-3BY present the highest quartz content $(\sim 7 \%)$. The rest of the quantified phases (cristobalite, cordierite, and gypsum) are present in similar proportions in the samples where they are present.

The section labeled as "others" was obtained by summing up of all components to $100 \%$. This section has the highest content in almost every sample (33.4\% to $60.6 \%)$ and represents the 
amorphous phase. In addition, this section includes a small amount of pyroxenes (not quantified because it was not possible to identify the type of pyroxene).

Table 1. Mineral quantification of analyzed natural clinkers.

\begin{tabular}{ccccccccc}
\hline \multirow{2}{*}{ Sample } & \multicolumn{7}{c}{ Mineral Phase (\%) } \\
\cline { 2 - 8 } & Quartz & Hematite & Mullite & Cristobalite & Hercynite & Cordierite & Gypsum & Others \\
\hline ESC-1 & 1.3 & 7.5 & 27.9 & 2.8 & - & 2.2 & - & 58.3 \\
ESC-2B & 3.2 & 4.1 & 16.3 & 1.9 & 5 & 1.3 & 7.6 & 60.6 \\
ESC-2BY & 6.9 & 5.2 & 33.5 & 4.5 & 1.3 & - & 3.3 & 45.3 \\
ESC-3B & 4.6 & 3.7 & 27.8 & 2.6 & 4.3 & 2.5 & - & 54.5 \\
ESC-3BY & 6.9 & 10 & 38 & 4.4 & 1.4 & - & 5.9 & 33.4 \\
ESC-4 & 1.7 & 9.5 & 35.4 & 5.5 & - & 1 & - & 46.9 \\
\hline
\end{tabular}

\subsection{Optical Microscopy}

The natural clinkers show similar textures at the scale of the optical microscope. In general, the samples present a vitreous appearance and high and heterometric porosity with pore sizes from less than $1 \mu \mathrm{m}$ to $5 \mathrm{~mm}$. This porosity is probably a consequence of the dehydroxylation of phyllosilicates and the carbonate and organic matter destabilization.

The natural clinkers are formed by both transparent and opaque minerals immersed in a fine-grained matrix below the optical resolution of the microscope. These three components are distributed heterogeneously in the samples. In general, opaque minerals are more abundant than transparent phases at this scale of observation. Opaque minerals are concentrated in the black areas and transparent minerals in the red and yellow ones.

Under reflected light, spinel (hercynite, according to the XRD results) and hematite were identified. The relative abundance of these minerals varies from sample to sample and even at sample scale. As indicated above, and in agreement with the XRD data, hercynite, and hematite were concentrated in the black areas and were immersed in a continuous gray matrix that could not be identified by this technique. Hercynite is found as exsolution lamellae in hematite crystals (Figure 3a) or forming replacement textures with hematite (Figure 3b).
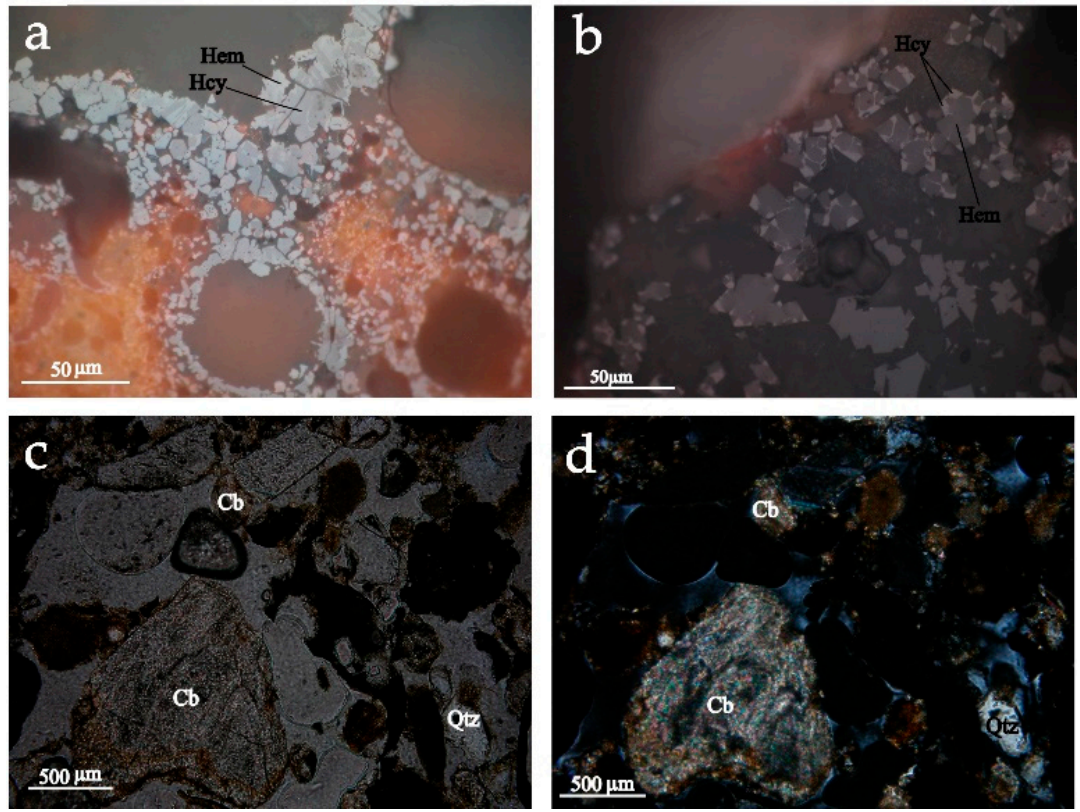

Figure 3. Reflected light optical microscopy images of hercynite and hematite in parallel nicols $(\mathbf{a}, \mathbf{b})$. Transmitted light optical microscopy images in parallel (c) and crossed nicols (d). Hem = hematite, Hcy = hercynite, $\mathrm{Cb}=$ carbonates, $\mathrm{Qtz}=$ quartz. 
Under transmitted light, the only transparent minerals that are observed are quartz and degraded carbonate-type grains immersed in a fine-grained matrix with particle sizes below optical microscope resolution. Quartz is found as anhedral to subhedral clasts, with common angular grain boundaries, whereas carbonates occur as highly altered irregular rock fragments (Figure 3c,d).

\subsection{Field-Emission Scanning Electron Microscopy (FESEM)}

Backscattered electron images (BSE) and chemical analyses (EDS) of the natural clinkers show that they are texturally and compositionally heterogeneous. Electron images made it possible to observe the different minerals already identified by $\mathrm{XRD}$, such as mullite, hematite, silica phases, pyroxenes, cordierite, and hercynite. Furthermore, pyrite and calcium oxides were detected by FESEM although they were not identified by XRD.

\subsubsection{Major Phases in the Natural Clinkers}

The major phases present in the studied samples according to the XRD results are mullite, hematite, hercynite, pyroxenes, cordierite, quartz, and cristobalite. All these phases are embedded in an $\mathrm{Al}+$ Si-rich vitreous groundmass.

The mullite shows lenticular, acicular, and prismatic morphologies with random orientation. Its size is in general less than $1 \mu \mathrm{m}$ in length, but in some areas it can reach up to $2 \mu \mathrm{m}$ in length (Figure 4a).
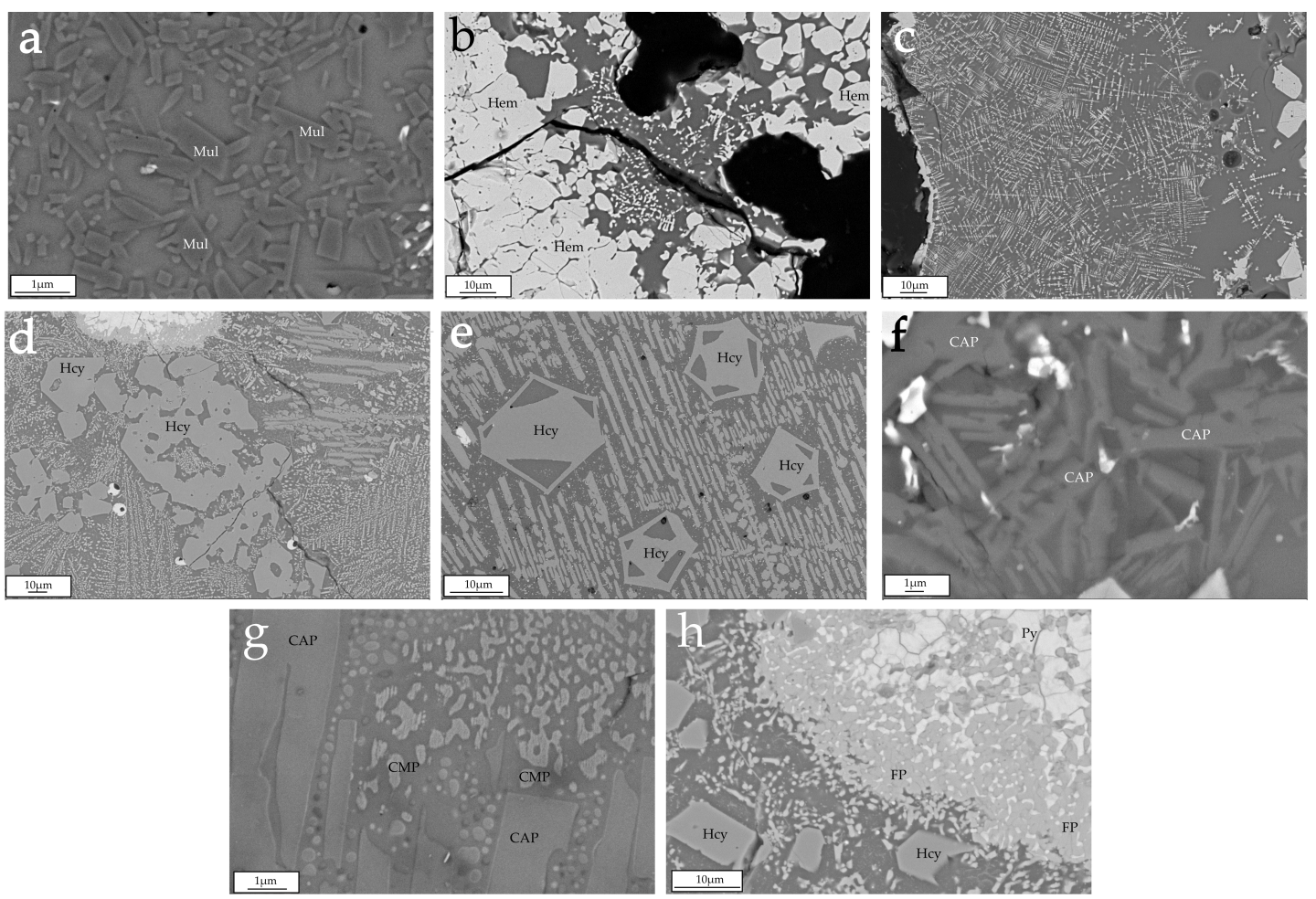

Figure 4. Backscattered electron images (BSE) images of (a) micron-sized mullite crystals with random orientation; (b) prismatic and subeuhedral hematite crystals; (c) dendritic hematite crystals; (d) subeuhedral hercynite crystals; (e) hercynite crystals with polygonal sections; (f) acicular Ca-Al-rich pyroxene crystals; (g) Ca-Mg-rich pyroxene crystals, with rounded morphologies associated with Ca-Al-rich pyroxenes; and (h) Fe-rich pyroxenes surrounding pyrite crystals. Mul = mullite, $\mathrm{Hem}=$ hematite $\mathrm{Hcy}=$ hercynite, $\mathrm{CAP}=\mathrm{Ca}-\mathrm{Al}$-rich pyroxene, $\mathrm{CMP}=\mathrm{Ca}-\mathrm{Mg}$-rich pyroxene and $\mathrm{FP}=$ Fe-rich pyroxene.

Hematite is present in all the samples and forms crystalline aggregates with different crystal morphologies and sizes. On the one hand, it occurs as anhedral crystals 1-20 $\mu \mathrm{m}$ in diameter, sometimes 
arranged in a mosaic-like texture (Figure $4 \mathrm{~b}$ ). On the other hand, it appears as dendritic and arborescent aggregates (Figure 4c), and it is also present as hexagonal plates smaller than $1 \mu \mathrm{m}$.

Hercynite is observed on the one hand as micron-sized euhedral to subeuhedral grains (Figure 4d), and in some cases as skeletal crystals showing polygonal sections, most of them hexagonal (Figure 4e). On the other hand, hercynite lamellae, 1-2 $\mu \mathrm{m}$ wide and 1-6 $\mu \mathrm{m}$ long, are observed within hematite crystals suggesting the development of exsolution processes (Figure 5a,b). The textural relationship between hercynite and hematite is correlated with EDS analyses of these phases, which are explained in the next section. Furthermore, replacement textures are observed between hematite and hercynite, where hercynite is replacing hematite (Figure 5c). In some cases, hercynite is replacing hematite from the nucleus (Figure 5e). In addition, hercynite lamellae are identified within cordierite crystals (Figure 5d); as in the case of hematite, this suggests exsolution processes between these two phases.
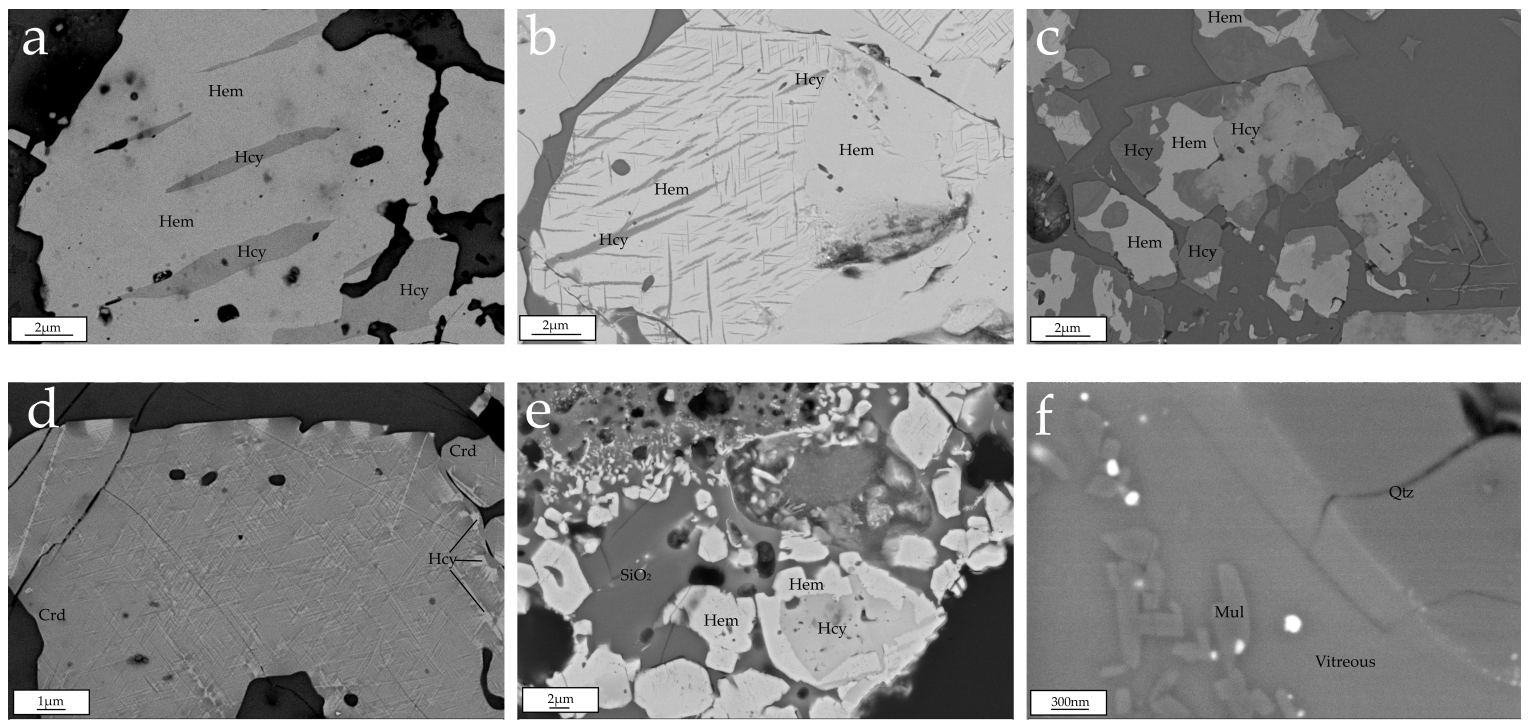

Figure 5. BSE images of $(\mathbf{a}, \mathbf{b})$ hercynite lamellae in hematite crystals, (c) replacement texture between hematite and hercynite, (d) hercynite lamellae in cordierite crystal, (e) hercynite nucleus in hematite crystal and silica phase filling the spaces among the crystals, and (f) quartz fragment with reaction edge. $\mathrm{Hem}=$ hematite, $\mathrm{Hcy}=$ hercynite, $\mathrm{Crd}=$ cordierite, $\mathrm{SiO}_{2}=$ silica phases, $\mathrm{Mul}=$ mullite, $\mathrm{Qtz}=$ quartz, Vitreous = vitreous phase.

According to their chemical composition, three different groups of pyroxenes were distinguished: calcium- and aluminium-rich, calcium- and magnesium-rich, and iron-rich pyroxenes. Besides the differences in chemical composition, these show different textural features. Ca- and Al-rich pyroxenes are closely associated with hematite, hercynite and other pyroxenes, and appear randomly distributed in the matrix as micron-sized acicular crystals with no preferred orientation (Figure $4 \mathrm{f}$ ).

Ca- and Mg-rich pyroxenes appear as rounded crystals smaller than $1 \mu \mathrm{m}$, and are randomly distributed throughout the matrix (Figure 4g). They are texturally associated with the Ca- and Al-rich pyroxenes.

Fe-rich pyroxenes appear as rounded crystals smaller than $1 \mu \mathrm{m}$, as well as lenticular crystals with sizes greater than $10 \mu \mathrm{m}$. Occasionally, rounded crystals of Fe-rich pyroxene are in close relationship with pyrite, appearing in the outer limits of mosaic-like pyrite aggregates (Figure 4h), suggesting that these pyroxenes could be replacing pyrite crystals.

A silica phase is observed as a groundmass filling the spaces among the crystals (Figure 5e). From the XRD data it can be inferred that this phase corresponds to cristobalite. Furthermore, quartz fragments larger than $2 \mu \mathrm{m}$ and showing reaction edges (Figure 5f) were recognized. These quartz fragments were probably already present in the previous clay. 


\subsubsection{Minor Phases in the Natural Clinkers}

FESEM images revealed minor phases such as calcium oxides and pyrite that were not detected by XRD. Calcium oxides appear as microcrystalline aggregates with sizes of $\sim 50 \mu \mathrm{m}$ (Figure $6 \mathrm{a}$ ), which may come from carbonates in the precursor clay that have been destabilized with the spontaneous combustion.
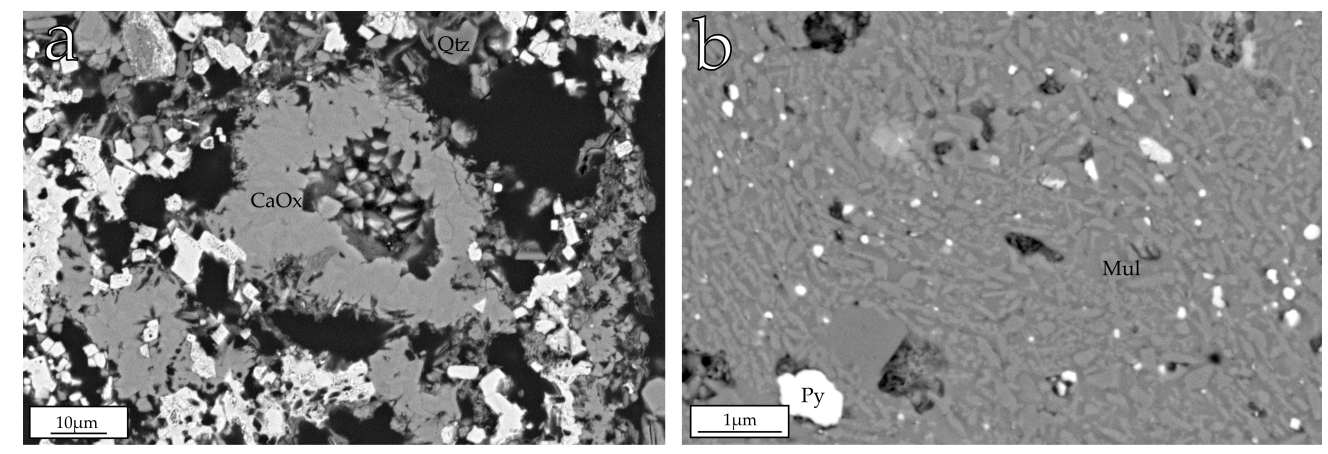

Figure 6. BSE images of (a) microcrystalline aggregates of calcium oxides and (b) anhedral pyrite crystals. $\mathrm{CaOx}=$ calcium oxides, $\mathrm{Qtz}=$ quartz, $\mathrm{Mul}=$ mullite, $\mathrm{Py}=$ pyrite.

Pyrite appears as anhedral crystals smaller than $1 \mu \mathrm{m}$, immersed in a gray matrix, probably vitreous (Figure 6b), and associated with mullite, pyroxenes, and quartz fragments. Pyrite and quartz were present in the original rock and probably remained stable with the increase in temperature.

\subsubsection{Chemical Analyses}

EDS analyses of the major phases are shown in Table 2. As the analyses indicate, mullite has an Al-Si composition with minor proportions of Fe and Ti. Theoretical mullite has a Si/Al ratio of 0.35 , whereas our analyses show an average $\mathrm{Si} / \mathrm{Al}$ ratio of 1.21 and an average $\mathrm{Si} /(\mathrm{Al}+\mathrm{Fe}+\mathrm{Ti})$ ratio of 1.13 , indicating that the analyzed mullite is richer in Si than expected.

Table 2. Chemical composition (wt \%) of all the mineral phases detected in the studied samples and average structural formula calculated. $n=$ number of analysis; standard deviation in brackets.

\begin{tabular}{|c|c|c|c|c|c|c|c|c|c|c|}
\hline \multirow{2}{*}{ Analyzed Phases } & \multicolumn{9}{|c|}{ wt $\%$} & \multirow{2}{*}{ Calculated Average Formula } \\
\hline & $\mathbf{O}$ & $\mathrm{Na}$ & $\mathrm{Mg}$ & Al & Si & $\mathbf{K}$ & $\mathrm{Ca}$ & $\mathrm{Ti}$ & $\mathbf{F e}$ & \\
\hline \multirow{2}{*}{$\begin{array}{l}\text { Hematite } \\
(n=14)\end{array}$} & 37.7 & - & - & 2.3 & - & - & - & - & 59.6 & \multirow{2}{*}{$\mathrm{Al}_{0.1} \mathrm{Fe}_{1.9} \mathrm{O}_{3}$} \\
\hline & (1.7) & - & - & $(1.5)$ & - & - & - & - & $(1.8)$ & \\
\hline \multirow{2}{*}{$\begin{array}{l}\text { Hercynite } \\
(n=21)\end{array}$} & 44.6 & - & 1.8 & 27 & - & - & - & 0.4 & 26.1 & \multirow[b]{2}{*}{$\mathrm{Mg}_{0.1} \mathrm{Fe}_{0.8} \mathrm{Al}_{1.7} \mathrm{O}_{4}$} \\
\hline & $(3.8)$ & - & $(1.8)$ & $(7.6)$ & - & - & - & $(0.2)$ & $(7.0)$ & \\
\hline \multirow{2}{*}{ Mullite $(n=23)$} & 51.3 & - & - & 21.4 & 25.9 & - & - & 0.3 & 1.1 & \multirow{2}{*}{$\mathrm{Fe}_{0.1} \mathrm{Al}_{2.3} \mathrm{Si}_{2.9} \mathrm{O}_{9.75}$} \\
\hline & $(9.1)$ & - & - & $(5.5)$ & $(4.9)$ & - & - & $(0.1)$ & $(0.9)$ & \\
\hline $\begin{array}{c}\text { "Ceramic pyroxenes" } \\
(n=9)\end{array}$ & $\begin{array}{l}53.7 \\
(0.9)\end{array}$ & $\begin{array}{c}0.4 \\
(0.2)\end{array}$ & $\begin{array}{c}0.1 \\
(0.2)\end{array}$ & $\begin{array}{l}12.6 \\
(1.3)\end{array}$ & $\begin{array}{l}22.8 \\
(2.2)\end{array}$ & $\begin{array}{c}0.4 \\
(0.3)\end{array}$ & $\begin{array}{c}8.5 \\
(1.5)\end{array}$ & $\begin{array}{c}0.1 \\
(0.1)\end{array}$ & $\begin{array}{c}1.5 \\
(0.9)\end{array}$ & $\mathrm{Ca}_{0.5} \mathrm{Fe}_{0.1} \mathrm{Al}_{1}\left(\mathrm{Al}_{0.1} \mathrm{Si}_{1.9}\right) \mathrm{O}_{6}$ \\
\hline \multirow{2}{*}{$\begin{array}{c}\text { Cordierite } \\
(n=3)\end{array}$} & 45.6 & - & 1.4 & 16 & 5.4 & - & - & 0.8 & 30.9 & \multirow{2}{*}{$\left(\mathrm{Mg}_{0.5} \mathrm{Fe}_{1.6}\right)\left(\mathrm{Fe}_{1.4 \mathrm{Ti}_{0.1}}\right)\left(\mathrm{Si}_{2.6} \mathrm{Al}_{2.4}\right) \mathrm{Al}_{2.8} \mathrm{O}_{18}$} \\
\hline & (2.2) & - & $(0.0)$ & $(0.1)$ & $(3.8)$ & - & - & $(0.1)$ & (5.8) & \\
\hline \multirow{2}{*}{$\begin{array}{l}\text { Silica phases } \\
\quad(n=4)\end{array}$} & 50.7 & - & - & 1.4 & 48 & - & - & - & - & \multirow{2}{*}{$\mathrm{Al}_{0.1} \mathrm{Si}_{0.9} \mathrm{O}_{2}$} \\
\hline & (10.1) & - & - & (1.3) & (10.6) & - & - & - & - & \\
\hline \multirow{2}{*}{$\begin{array}{l}\text { Fe-pyroxenes } \\
\quad(n=3)\end{array}$} & 45.6 & - & 1.1 & 4.1 & 18.8 & - & 0.7 & 0.3 & 29.4 & \multirow{2}{*}{$\mathrm{Al}_{0.1} \mathrm{Mg}_{0.1} \mathrm{Fe}_{1.3}\left(\mathrm{Al}_{0.3} \mathrm{Si}_{1.7}\right) \mathrm{O}_{6}$} \\
\hline & $(0.2)$ & - & (0.3) & $(0.1)$ & $(0.4)$ & - & $(0.1)$ & $(0.1)$ & $(0.6)$ & \\
\hline \multirow{2}{*}{$\begin{array}{l}\text { Ca-Mg pyroxenes } \\
(n=4)\end{array}$} & 54.1 & - & 2 & 5.2 & 27.4 & - & 6.9 & 0.1 & 4.3 & \multirow{2}{*}{$\left(\mathrm{Al}_{0.4} \mathrm{Mg}_{0.2} \mathrm{Fe}_{0.2} \mathrm{Ca}_{0.4}\right) \mathrm{Si}_{2.3} \mathrm{O}_{6}$} \\
\hline & $(0.3)$ & - & $(0.6)$ & $(1.0)$ & $(1.0)$ & - & $(0.6)$ & 0 & $(0.6)$ & \\
\hline \multirow{2}{*}{$\begin{array}{l}\text { Vitreous phase } \\
\quad(n=25)\end{array}$} & 48.8 & 0.2 & 1.1 & 11.6 & 30.9 & 2.4 & 1.4 & 0.2 & 2.9 & \\
\hline & (9.6) & $(0.2)$ & (1.6) & (7.3) & $(6.5)$ & (1.3) & (1.6) & $(0.2)$ & (2.7) & \\
\hline
\end{tabular}

Hematite and hercynite show compositional differences from sample to sample and even at sample scale. Figure 7 shows the $\mathrm{Al}$ vs. Fe contents (wt \%) in these phases, indicating a trend from hematite to hercynite compositions. Taking into account all the analyses obtained from these phases, 
those with Fe contents higher than 56\% and $\mathrm{Al}$ contents lower than 5\% were considered to be hematite. Conversely, those analyses with Fe contents lower than $40 \%$ and $\mathrm{Al}$ contents higher than $18 \%$ were considered to be hercynite. The rest of the analyses, which are not included within these limits, were considered to be intermediate compositions. On average, the hematite composition is close to the theoretical one $(69.9 \% \mathrm{Fe}$ and $30 \% \mathrm{O})$, with a $59.6 \%$ content in $\mathrm{Fe}$, but it also contains minor proportions of $\mathrm{Al}(2.3 \%)$. As regards the hercynite composition, the $\mathrm{Al}(27 \%)$ and $\mathrm{Fe}(26.1 \%)$ contents are lower than the theoretical ones $(31.05 \% \mathrm{Al}, 32.13 \% \mathrm{Fe}$, and $36.82 \% \mathrm{O})$.

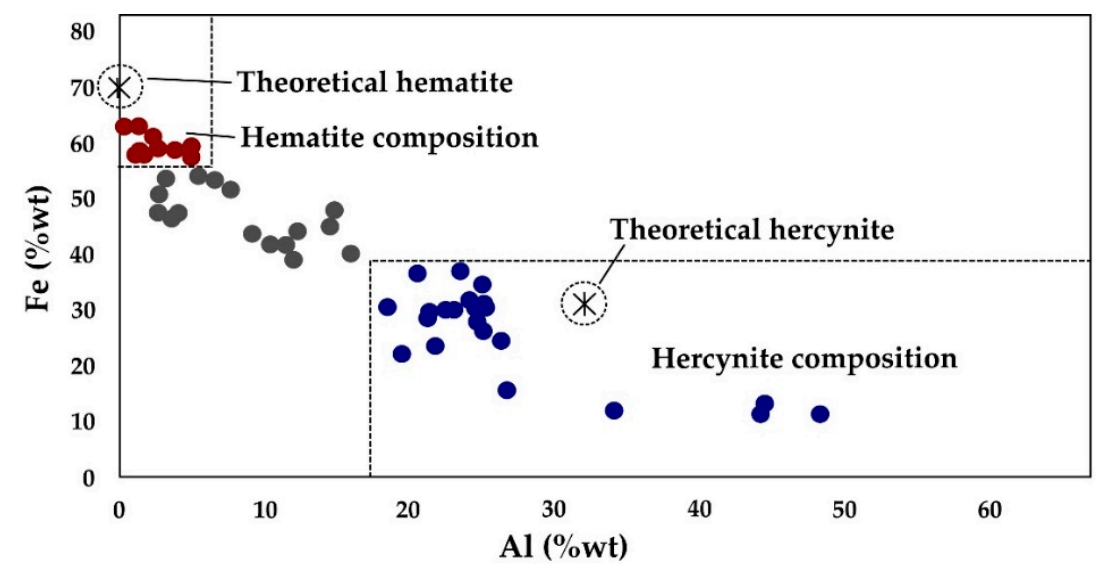

Figure 7. Al vs. Fe (wt \%) graph showing hematite and hercynite composition.

Regarding pyroxenes, as mentioned above, three different compositional types were observed. The $\mathrm{Ca}$ - and $\mathrm{Al}$-rich pyroxenes show low $\mathrm{Fe}, \mathrm{Na}, \mathrm{K}, \mathrm{Mg}$, and Ti contents. Their average structural formula is $\mathrm{Ca}_{0.5} \mathrm{Fe}_{0.1} \mathrm{Al}_{1}\left(\mathrm{Al}_{0.1} \mathrm{Si}_{1.9}\right) \mathrm{O}_{6}$, and thus their composition may be described as intermediate between the fassaite compositions, reported by several authors [21,22], diopside, and esseneite [23] (Figure 8). Previous researchers have used the term "ceramic pyroxene" to refer to pyroxenes with an intermediate composition between fassaite and diopside [21,22]. Thus, in this study Ca- and Al-rich pyroxenes are called "ceramic pyroxenes".

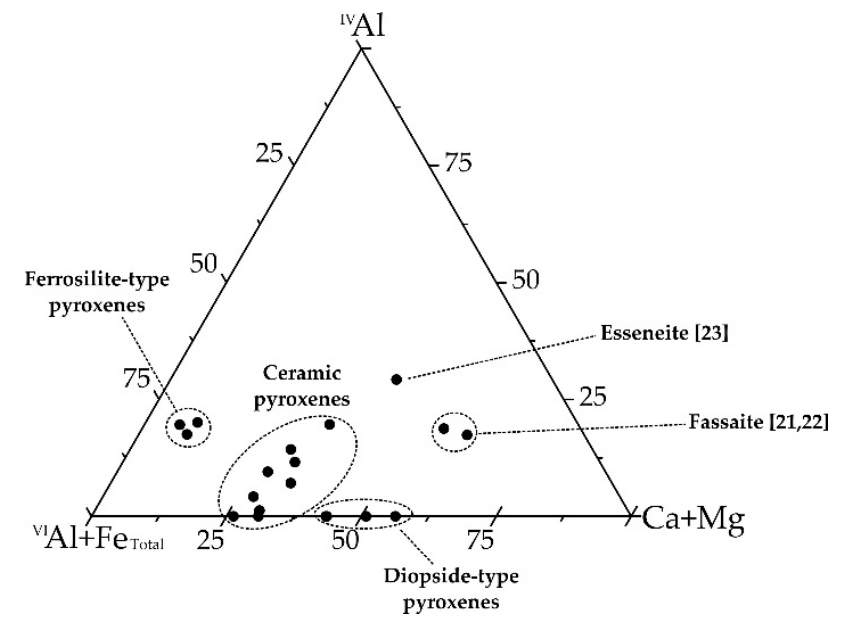

Figure 8. Plot of the EDS pyroxene compositions normalized on the basis of 6 oxygens in a ${ }^{\mathrm{IV}} \mathrm{Al}-{ }^{\mathrm{VI}} \mathrm{Al}$ $+\mathrm{Fe}_{\text {total }}-\mathrm{Ca}+\mathrm{Mg}$ diagram. Esseneite and fassaite compositions from the literature [21-23] have also been plotted as reference.

The compositions of the Ca- and Mg-rich and Fe-rich pyroxenes are plotted in Figure 9, showing that these groups have clearly different compositions. These compositions are close to diopside and ferrosilite compositions, respectively. 


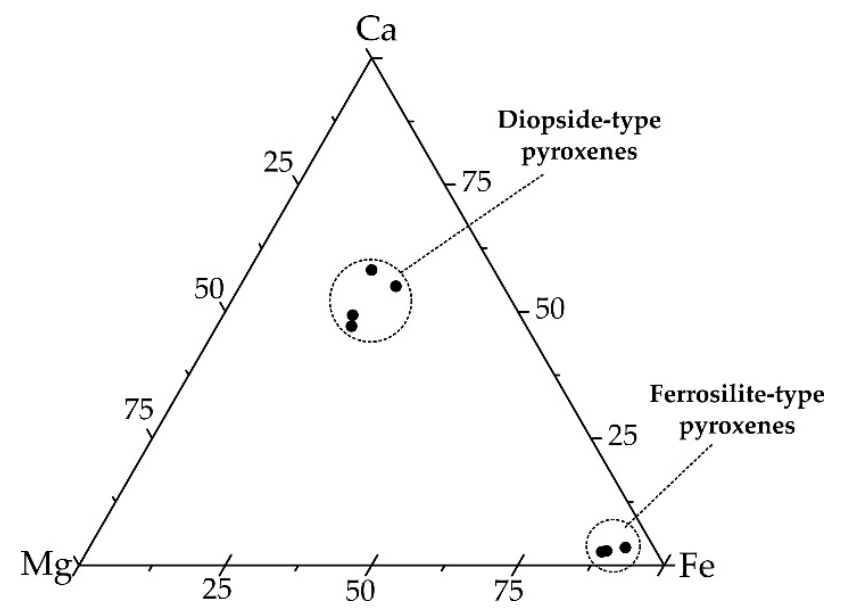

Figure 9. Plot of the EDS Ca-Mg-rich and Fe-rich pyroxene compositions normalized on the basis of 6 oxygens in a $\mathrm{Ca}-\mathrm{Mg}-\mathrm{Fe}$ diagram. The diagram shows the compositional differences between diopside- and ferrosilite-type pyroxenes.

The analyzed diopside-type pyroxenes present lower $\mathrm{Ca}(6.9 \%)$ and $\mathrm{Mg}(2 \%)$ contents than the theoretical diopside $(18.51 \% \mathrm{Ca}, 11.22 \% \mathrm{Mg}, 25.94 \% \mathrm{Si}$, and $44.33 \% \mathrm{O})$, and they also contain $\mathrm{Fe}, \mathrm{Al}$, and minor proportions of Ti. The average structural formula of these phases is $\left(\mathrm{Al}_{0.4} \mathrm{Mg}_{0.2} \mathrm{Fe}_{0.2} \mathrm{Ca}_{0.4}\right) \mathrm{Si}_{2.3} \mathrm{O}_{6}$. Similarly, a comparison of the Fe-rich pyroxene with ferrosilite shows it to have lower $\mathrm{Si}(18.8 \%)$ and $\mathrm{Mg}(1.1 \%)$ contents and higher Fe (29.4\%) content than the theoretical composition $(10.46 \% \mathrm{Mg}, 24.04 \%$ $\mathrm{Fe}, 24.18 \% \mathrm{Si}$, and $41.32 \% \mathrm{O}$ ), with an average structural formula $\mathrm{Al}_{0.1} \mathrm{Mg}_{0.1} \mathrm{Fe}_{1.3}\left(\mathrm{Al}_{0.3} \mathrm{Si}_{1.7}\right) \mathrm{O}_{6}$. It also contains $\mathrm{Al}$ and minor proportions of $\mathrm{Ca}$ and $\mathrm{Ti}$.

The analyzed cordierite presents high $\mathrm{Fe}(30.9 \%)$ and $\mathrm{Al}(16 \%)$ contents and low $\mathrm{Si}, \mathrm{Mg}$, and $\mathrm{Ti}$ contents. Compared with the theoretical composition $(8.31 \% \mathrm{Mg}, 18.45 \% \mathrm{Al}, 24.01 \% \mathrm{Si}$, and $49.23 \% \mathrm{O}$ ), the analyzed cordierite is Mg- and Si- poor and Fe-rich.

Finally, the groundmass of all the studied samples presents a heterogeneous Al- and Si-rich composition, with minor $\mathrm{Fe}, \mathrm{K}, \mathrm{Mg}, \mathrm{Ca}$, $\mathrm{Ti}$, and $\mathrm{Na}$ contents. It can be deduced that it corresponds to the vitreous phase detected by XRD.

\section{Discussion}

\subsection{Destabilization of the Initial Phases}

The natural clinkers initially contained organic matter, abundant kaolinite and illite and minor proportions of quartz, $\mathrm{K}$ feldspar, siderite, pyrite, and Ti and Fe oxides [32]. Most of these phases were destabilized and melted during the spontaneous combustion of coal.

The calcium oxides observed by FESEM may come from small amounts of carbonates present in the precursor clays that have been destabilized, as suggested by optical microscopy observations of degraded carbonate fragments. Carbonate destabilization can generate not only these calcium oxides, but also other Ca-rich phases such as pyroxenes [22].

Organic matter is eliminated between 200 and $800{ }^{\circ} \mathrm{C}$, although this depends on its content in the precursor material [36]. In addition, kaolinite, illite, and $\mathrm{K}$ feldspar are not detected in the studied natural clinkers, indicating that they have been destabilized, as described by other authors [20,37], and that they are therefore less stable phases than quartz or pyrite. Kaolinite is not stable at temperatures above $200^{\circ} \mathrm{C}$ in natural environments [38]. Similarly, metamorphic rocks such as those from greenschist facies do not contain illite, which indicates that it is not stable above $350{ }^{\circ} \mathrm{C}$. With regard to $\mathrm{K}$ feldspars, it is possible that they were destabilized during the spontaneous combustion due to their low content in the precursor clays. 
The oxidation of pyrite and siderite results in hematite and magnetite $[39,40]$, the former of which was identified in the study samples. In addition, when pyrite is oxidized, aqueous, acidic, and sulfate-rich solutions are produced [41]. These solutions, along with the presence of calcite, produce sulfate minerals such as gypsum. Accordingly, $\mathrm{SO}_{4}{ }^{2-}$ released from pyrite oxidation, along with Ca from carbonates, allows gypsum precipitation [42], as it is identified by XRD in some of the studied samples.

Finally, quartz is also observed, indicating that it is the most stable phase during combustion, although it shows reaction edges, which suggest that it is partially destabilized due to the high-temperatures.

\subsection{Crystallization of New Phases}

\subsubsection{Hematite, Hercynite and Cordierite}

Hematite, magnetite, hercynite, and cordierite are frequently described in natural clinkers [11,13,16-18]. In the studied natural clinkers hematite, hercynite and cordierite were observed. Their textures are clearly related to neoformation associated with the combustion process.

Exsolution textures were observed between hematite and hercynite, as well as between cordierite and hercynite. These textures occur frequently as a consequence of cooling from a melted mass, in this case resulting from the spontaneous combustion process. With cooling, lamellae are separated within the host crystals due to differences in cation sizes, since at high-temperatures crystal structures can accommodate cations of different size more easily. However, at lower temperatures, the range of possible substitutions of different-sized cations is much less.

The existence both of magnetite exsolution lamellae in hercynite and of hercynite exsolution lamellae in magnetite has been previously described [11,43]. Solid solutions between both bases are also described in natural clinkers [13,43]. These textures are also formed in igneous and metamorphic rocks [26,44,45]. Furthermore, previous investigations have described titaniferous spinel intergrowths with hematite in igneous and metamorphic rocks and the possibility of a Zn-rich spinel formation that went into solution in cordierite in metamorphic rocks [44,46].

Magnetite was not detected by XRD in this study. This may be due to the fact that part of a primary magnetite may be pseudomorphed by hematite in a martitization process [43]. In this case, it is possible that remnant traces of the original magnetite may persist in the studied samples, which may not have been detected due to the low concentration. Another possibility is that hematite was formed during the spontaneous combustion instead of magnetite.

The existence of hercynite lamellae in magnetite crystals and vice versa suggests that both phases can occur as discrete phases at peak temperatures with substantial mutual solid solution [24]. However, the fact that the hercynite in the studied natural clinkers never contains exsolution lamellae supports the hypothesis that it has been exsolved from another phase. This phase could be a primary magnetite subsequently transformed into hematite, or it could be a hematite that crystallized during the spontaneous combustion instead of magnetite.

Figure 10 shows the Fe vs. Al content of hercynite crystals in different textural arrangements. Hercynite has a higher $\mathrm{Al}$ content and lower Fe content when it is found as scattered crystals or is involved in replacement textures with hematite $(24.2 \% \mathrm{Al}$ and $27.8 \% \mathrm{Fe})$. By contrast, the $\mathrm{Al}$ content is lower and the Fe content is higher when it forms exsolution lamellae within hematite $(5.9 \% \mathrm{Al}$ and $48.1 \% \mathrm{Fe})$ or cordierite (11.4\% $\mathrm{Al}$ and $40.8 \% \mathrm{Fe})$.

The replacement textures between hercynite and hematite imply that one mineral has been formed from another, so they are not coeval phases. A similar process where spinel is formed by replacement of magnetite, which reacts with the vitreous phase, is described in the literature [27]. This reaction could have occurred in the same way in the studied natural clinkers, with the later oxidation or martitization of magnetite to hematite.

Exsolution lamellae of hercynite within both hematite and cordierite were observed in sample ESC-2, whereas in sample ESC-3 such exsolution lamellae were only observed within hematite. 
This may be related to the above-mentioned differences in the $d_{(400)}$ values of hercynite observed in the XRD patterns of these two samples (8.208, 8.196 for ESC-2 and $8.168 \AA$ for ESC-3). Thus, a close relationship between the textural arrangement of hercynite and the compositional and structural variations of this mineral can be deduced. In other words, the hercynite composition is different when it appears as exsolved lamellae within hematite or cordierite, and it shows structural differences depending on the mineral from which the exsolution process occurred.

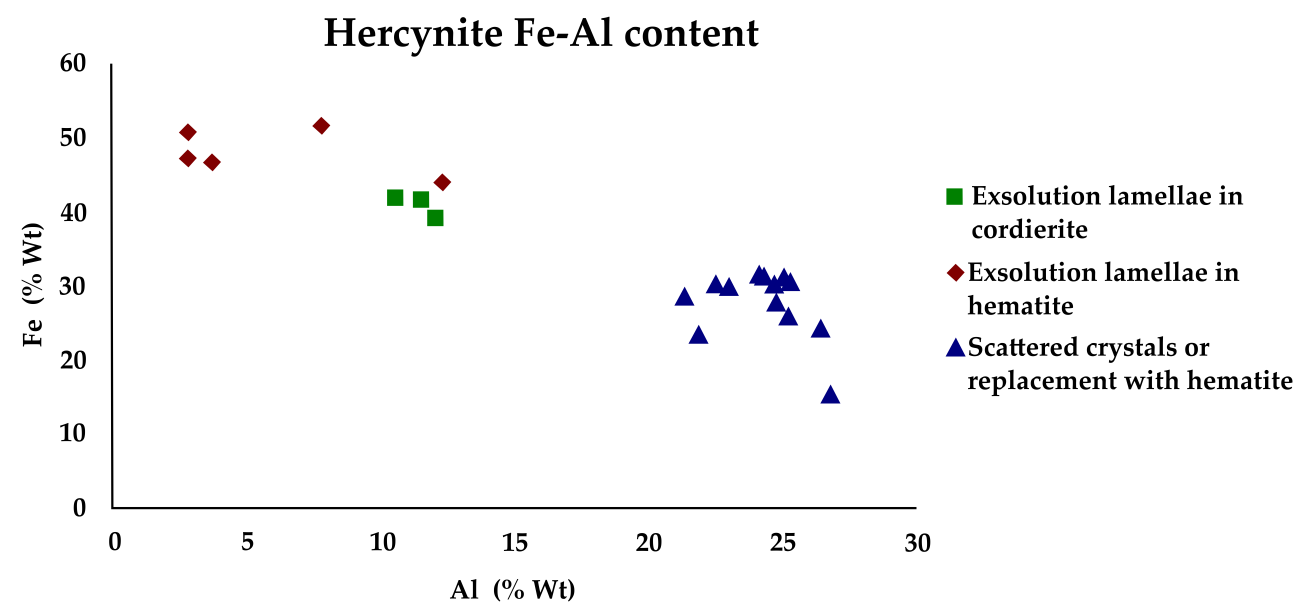

Figure 10. Fe vs. $\mathrm{Al}(\mathrm{wt} \%)$ content in hercynite crystals from samples ESC-2 and ESC-3. The proportion of the two elements depends on the way the crystals are arranged: exsolution lamellae in cordierite or hematite, or replacement textures with hematite or scattered crystals.

The hematite $d_{(104)}$ values are similar among samples ESC-2 and ESC-3, indicating that much of the detected hematite has a close composition to the theoretical one. This supports the hypothesis that the hematite may proceed from magnetite. If the hematite were crystallized from the vitreous phase, a higher $\mathrm{Al}$ content would be expected.

In hercynite exsolution lamellae within hematite, the cation size difference between $\mathrm{Al}$ and $\mathrm{Fe}$ favors the exsolution, although Fe-rich phases, Al-rich phases, and intermediate phases were able to form. In contrast, in hercynite exsolution lamellae within cordierite, the structural and compositional differences between the two phases preclude the existence of intermediate compositions.

The intermediate compositions between hematite and hercynite (Figure 7) may be due to the existence of nanometric exsolution textures, and thus EDS analyses may come from those areas where both phases are present. Alternatively, these intermediate analyses may also be reflecting the existence of minority solidus solutions that do not modify the $d_{(104)}$ values of hematite.

Finally, the idiomorphic skeletal textures that hercynite sometimes shows (Figure 4e) suggest its crystallization in two stages. A possible hypothesis that would explain this situation is the formation of a first-stage hercynite from the vitreous phase that was subsequently destabilized, giving rise to convex morphologies. After that, a euhedral hercynite could have crystallized in a second stage, surrounding the first crystals and including part of the vitreous phase.

\subsubsection{Mullite and Pyroxenes}

Mullite is present as 1-2 $\mu \mathrm{m}$-long lenticular, acicular, and prismatic crystals with random orientation. Previous, electron microprobe analyses of mullite formed by the spontaneous combustion of coal reported Al-rich mullite with a composition close to the theoretical formula ( $38 \mathrm{wt} \% \mathrm{Al}, 13.18 \mathrm{wt} \% \mathrm{Si}$, and $48.82 \mathrm{wt} \%$ O) [14].

However, chemical analyses of mullite in this study showed a $\mathrm{Si} / \mathrm{Al}$ ratio of 1.21 , which is higher than the theoretical ratio (0.35), indicating that this mullite is Si-rich. Analysis of mullite from aluminum-rich clays during ceramic firing also shows a nonstoichiometric Si-rich composition [20]. These authors explained that this is probably a consequence of the temperature and the length of time 
of the ceramic process. Similarly, the nonstoichiometric composition of mullite in the natural clinkers could be explained by the temperature reached and the duration of the spontaneous combustion in the studied area, which would not have provided ideal conditions for mullite crystals to reach the theoretical composition.

EDS analysis showed three pyroxene-type compositions: "ceramic pyroxenes", diopside-type, and ferrosilite-type.

The "ceramic pyroxenes" were observed as micron-sized acicular crystals texturally associated with the other pyroxenes. Previous researchers have defined an uncommon C2/c pyroxene called esseneite as a product of pyrometamorphism associated with naturally combusted coal seams, which is similar to some pyroxenes from our analysis [23]. Other investigations have described pyroxenes formed during ceramic processes whose compositions are close to a pyroxene known as fassaite [21,22]. Even though the chemical compositions of the "ceramic pyroxenes" presented in this research do not match completely with those of fassaite or esseneite, they have intermediate compositions between these pyroxenes and diopside (Figure 8).

Diopside has previously been reported in natural clinkers [2,12] as well as in igneous and metamorphic rocks and skarns $[47,48]$. In ceramics, it is described as a metastable calcium and/or magnesium phase formed by the reaction of calcite, quartz and aluminum clays [49]. The calculated formula for diopside-type in the analyzed natural clinkers $\left(\left(\mathrm{Al}_{0.4} \mathrm{Mg}_{0.2} \mathrm{Fe}_{0.2} \mathrm{Ca}_{0.4}\right) \mathrm{Si}_{2.3} \mathrm{O}_{6}\right)$ shows a lower $\mathrm{Ca}$ and $\mathrm{Mg}$ content and a higher Si content than the theoretical formula $\left(\mathrm{CaMgSi}_{2} \mathrm{O}_{6}\right)$.

Ferrosilite has been described in igneous rocks $[47,50]$. The melting of igneous crustal components at high-temperatures and very low, near-constant oxygen fugacity allow ferrosilite to crystallize [50]. Ferrosilite-type pyroxene in the studied natural clinkers $\left(\left(\mathrm{Al}_{0.4} \mathrm{Mg}_{0.1} \mathrm{Fe}_{1.3}\right) \mathrm{Si}_{1.7} \mathrm{O}_{6}\right)$ shows higher $\mathrm{Fe}$ and lower $\mathrm{Mg}$ contents than the theoretical ferrosilite $\left((\mathrm{FeMg}) \mathrm{SiO}_{3}\right)$.

As with the mullite composition, the fact that the analyzed pyroxenes do not coincide with the theoretical ones could have to do with the firing dynamics associated with the spontaneous combustion of coal.

\subsection{The Spontaneous Combustion of Coal and the Formation of the Vitreous Phase}

An Al- and Si-rich vitreous phase is formed by the destabilization of the initial phases due to the increase in temperature, and it represents approximately $50 \%$ of the samples. The $\mathrm{Al}$ and $\mathrm{Si}$ come from quartz, kaolinite, and illite. Furthermore, this vitreous phase also contains minor proportions of $\mathrm{K}$ (from $\mathrm{K}$ feldspar and illite), $\mathrm{Fe}$ (from siderite, pyrite, and illite), $\mathrm{Ca}$ (from carbonates), and $\mathrm{Mg}$ (from illite). Previous researchers have described the appearance of a vitreous phase from $800{ }^{\circ} \mathrm{C}$ due to the spontaneous combustion of coal and resulting from the destabilization of clay minerals and other phases present in the initial rocks [39].

The new mineralogy and texture found in the studied samples are similar to that of fired aluminum-rich ceramics where the vitreous phase starts to form from $1000{ }^{\circ} \mathrm{C}$ and, consequently, mineral phases also crystallize from that temperature [20]. Furthermore, previous investigations indicate that the temperature reached in the studied area was probably higher than $1050{ }^{\circ} \mathrm{C}$ and the calcination periods were longer than $100 \mathrm{~h} \mathrm{[18].}$

These differences in temperatures indicated in the literature for the formation of the vitreous phase and subsequent mineral transformations may be due to the fact that these firing processes are heterogeneous and their duration and intensity can vary within the stratum where the natural clinkers are found. In the case of spontaneous combustion, besides temperature and length of time, there are several parameters that influence the process of spontaneous heating and combustion in coal, such as factors relating to mining, geological parameters, and the chemical contents of coal [10]. These parameters affect the composition of the new mineral phases and explain the presence of nonstoichiometric phases such as mullite and pyroxenes.

The higher percentages of vitreous phase and mullite, together with the greater size of the mullite (1-2 $\mu \mathrm{m}$ in length), compared to those at $1000{ }^{\circ} \mathrm{C}$ in ceramics (nanometer mullite) [20], allow to 
deduce that, in our case, the temperature reached was higher than $1000{ }^{\circ} \mathrm{C}$. Furthermore, Mössbauer spectroscopy and CCSEM measurements of the transformation products formed from pyrite included in coal in the drop tube furnace test at gas temperatures from $1038^{\circ} \mathrm{C}$ to $1454^{\circ} \mathrm{C}$ have shown magnetite to be the dominant oxide formed [51].

In the studied samples, hematite may have resulted from magnetite martitization. Magnetite thus crystallized due to the spontaneous combustion and, in this case, the temperature reached could have been between 1000 and $1454{ }^{\circ} \mathrm{C}$.

\section{Conclusions}

Spontaneous combustion of coal generates textural and compositional changes in the precursor kaolinite-rich clays. These changes include the destabilization of original phases, giving rise to the genesis of an Al-Si-rich vitreous phase, and the subsequent crystallization of new mineral phases. These phases are similar to those formed in a ceramic process as well as in metamorphic and igneous environments.

The trend from hematite to hercynite composition indicate variations at sample scale, which are reflected in XRD patterns evidenced in crystallochemical parameters in hercynite. This suggests structural variations that can be related to the $\mathrm{Al}$ and $\mathrm{Fe}$ content in hercynite depending on its texture: exsolution lamellae within hematite $(5.9 \% \mathrm{Al}$ and $48.1 \% \mathrm{Fe})$, exsolution lamellae within cordierite $(11.4 \% \mathrm{Al}$ and $40.8 \% \mathrm{Fe})$, and replacement textures with hematite, as well as scattered hercynite crystals $(24.2 \% \mathrm{Al}$ and $27.8 \% \mathrm{Fe})$.

The analyzed mullite is $\mathrm{Si}$-rich $(\mathrm{Si} / \mathrm{Al}=1.21)$ and nonstoichiometric compared with the theoretical mullite.

The study shows the crystallization of three different types of pyroxenes: diopside-type, ferrosilite-type, and a Ca-Al-rich pyroxene ("ceramic pyroxene") with an intermediate composition between that of diopside, fassaite, and esseneite. Compared with the theoretical compositions, the analyzed pyroxenes are nonstoichiometric.

The presence of nonstoichiometric phases could be explained by the short duration of the spontaneous combustion, which would not favor the formation of phases reaching the theoretical composition.

The higher percentages of vitreous phase and the larger size of mullite crystals compared with those of the ceramic process support the idea that the temperature would have reached more than $1000^{\circ} \mathrm{C}$.

Finally, the combination of XRD and electron microscopy has enabled a detailed characterization of the texture of the natural clinkers and the newly formed phase composition. The study of these new phases allows them to be compared with those formed during natural and ceramic processes and thus deepens our understanding of high-temperature crystallization processes.

Author Contributions: Conceptualization, E.L., B.B., and A.Y.; Formal Analysis, E.L.; Funding Acquisition, B.B.; Investigation, E.L., B.B., and A.Y.; Methodology, E.L. and B.B.; Project Administration, B.B.; Resources, B.B. and A.Y.; Supervision, B.B. and A.Y.; Validation, B.B. and A.Y.; Visualization, E.L.; Writing-Original Draft, E.L.; Writing-Review \& Editing, E.L., B.B., and A.Y.

Funding: This research and the APC were funded by the European Regional Development Fund and the Government of Aragón (Grupo Aragosaurus: Recursos Geológicos y Paleoambientes), grant number CGL2017-85038-P.

Acknowledgments: The authors would like to acknowledge the use of the Servicio General de Apoyo a la Investigación-SAI, University of Zaragoza. They would also like to thank C. Gallego for her advice during the FESEM sessions. E.L. also thanks the Government of Aragón grant for the development her Ph.D.

Conflicts of Interest: The authors declare no conflicts of interest. 


\section{References}

1. Smith, M.A.; Glasser, D. Spontaneous combustion of carbonaceous stockpiles. Part I. The relative importance of various intrinsic coal properties and properties of the reaction system. Fuel 2005, 84, 1151-1160. [CrossRef]

2. Querol, X.; Zhuang, X.; Font, O.; Izquierdo, M.; Alstuey, A.; Castro, I.; Van Drooge, B.L.; Moreno, T.; Grimalt, J.O.; Elvira, J.; et al. Influence of soil cover on reducing the environmental impact of spontaneous coal combustion in coal waste gobs: A review and new experimental data. Int. J. Coal Geol. 2011, 85, 2-22. [CrossRef]

3. Misra, B.K.; Singh, B.D. Susceptibility to spontaneous combustion of Indian coals and lignites: an organic petrographic autopsy. Int. J. Coal Geol. 1994, 25, 265-286. [CrossRef]

4. Querol, X.; Izquierdo, M.; Monfort, E.; Alvarez, E.; Font, O.; Moreno, T.; Alastuey, A.; Zhuang, X.; Lu, W.; Wang, Y. Environmental characterization of burnt coal gangue banks at Yangquan, Shanxi Province, China. Int. J. Coal Geol. 2008, 75, 93-104. [CrossRef]

5. Quintero, J.A.; Candela, S.A.; Ríos, C.A.; Montes, C.; Uribe, C. Spontaneous combustion of the Upper Paleocene Cerrejón Formation coal and generation of Clinker in La Guajira Peninsula (Caribbean Region of Colombia. Int. J. Coal Geol. 2009, 80, 196-210. [CrossRef]

6. Ribeiro, J.; Ferreira da Silva, E.; Flores, D. Burning of coal waste piles from Douro Coalfield (Portugal): Petrological, geochemical and mineralogical characterization. Int. J. Coal Geol. 2010, 81, 359-372. [CrossRef]

7. Misz-Kennan, M.; Fabiańska, M. Thermal transformation of organic matter in coal waste from Rymer Cones (Upper Silesian Coal Basin, Poland). Int. J. Coal Geol. 2010, 81, 343-358. [CrossRef]

8. Zhao, X.; Wang, Q.; Xiao, H.; Mao, Z.; Chen, P.; Sun, J. Prediction of coal stockpile autoignition delay time using micro-calorimeter technique. Fuel Process. Technol. 2013, 110, 86-93. [CrossRef]

9. Xu, Y.L.; Wang, L.Y.; Tian, N.; Zhang, J.P.; Yu, M.G.; Delichatsios, M.A. Spontaneous combustion coal parameters for the Crossing-Point Temperature (CPT) method in a Temperature-Programmed System (TPS). Fire Saf. J. 2017, 91, 147-157. [CrossRef]

10. Sinha, A.; Singh, V.K. Spontaneous Coal Seam Fires: A Global Phenomenon. In Spontaneous Coal Seam Fires: Mitigating a Global Disaster; Voigt, S., Rüter, H., Jiahong, L., Jayakumar, R., Eds.; ERSEC Ecological Book Series-4, Beijing, China, 29 November-1 December 2005; Tsinghua University Press: Beijing, China, 2005; pp. $41-66$.

11. Cosca, M.A.; Essene, E.J.; Geissman, J.W.; Simmons, W.B.; Coates, D.A. Pyrometamorphic rocks associated with naturally burned coal beds, Powder River Basin, Wyoming. Am. Mineral. 1989, 74, 85-100.

12. Foit, F.F.; Hooper, R.L.; Rosenberg, P.E. An unusual pyroxene, melilite, and iron oxide mineral assemblage in a coal-fire buchite from Buffalo, Wyoming. Am. Mineral. 1987, 72, 137-147.

13. Henao, J.A.; Carreño, A.M.; Quintero, J.A.; Candela, S.A.; Ríos, C.A.; Ramos, M.A.; Pinilla, J.A. Petrography and application of the Rietveld method to the quantitative analysis of phases of natural Clinker generated by coal spontaneous combustion. Earth Sci. Res. J. 2010, 14, 17-30.

14. Sokol, E.; Volkova, N.; Lepezin, G. Mineralogy of pyrometamorphic rocks associated with naturally burned coal-bearing spoil-heaps of the Chelyabinsk coal basin, Russia. Eur. J. Mineral. 1998, 10, 1003-1014. [CrossRef]

15. Ciesielczuk, J.; Misz-Kennan, M.; Hower, J.C.; Fabiańska, M.J. Mineralogy and geochemistry of coal wastes from the Starzykowiec coal-waste dump (Upper Silesia, Poland). Int. J. Coal. Geol. 2014, 127, 42-55. [CrossRef]

16. Ribeiro, J.; Suárez-Ruiz, I.; Flores, D. Geochemistry of self-burning coal mining residues from El Bierzo Coalfield (NW Spain): Environmental implications. Int. J. Coal. Geol. 2016, 159, 155-168. [CrossRef]

17. Baboolal, A.A.; Knight, J.; Wilson, B. Petrography and mineralogy of pyrometamorphic combustion metamorphic rocks associated with spontaneous oxidation of lignite seams of the Erin Formation, Trinidad. J. S. Am. Earth. Sci. 2018, 82, 181-192. [CrossRef]

18. Alastuey, A.; Bastida, J.; Fernández-Turiel, J.L.; Querol, X.; Signes, M. Mineralogía de las arcillas calcinadas de la base de la Fm. Escucha en el área de Foz-Calanda. Cuadernos de Geología Ibérica 1993, 17, 171-184.

19. Besteiro, J.; Bastida, J.; Amigó, J.M.; Lores, M.T.; López Buendía, A.; Serrano, F.J. Sobre análisis microestructural por DRX y condiciones de formación de mullitas naturales de la cuenca de Oliete (Teruel). Bol. Soc. Esp. Min. 1996, 19, 119-129.

20. Laita, E.; Bauluz, B. Mineral and textural transformations in aluminium-rich clays during ceramic firing. Appl. Clay Sci. 2018, 152, 284-294. [CrossRef] 
21. Dondi, M.; Ercolani, G.; Fabbri, B.; Marsigli, M. An approach to the chemistry of pyroxenes formed during the firing of Ca-rich silicate ceramics. Clay Miner. 1998, 33, 443-452. [CrossRef]

22. Bauluz, B.; Mayayo, M.J.; Yuste, A.; Fernandez-Nieto, C.; González López, J.M. Tem study of mineral transformations in fired carbonated clays: Relevance to brick making. Clay Miner. 2004, 39, 333-344. [CrossRef]

23. Cosca, M.A.; Peacor, D.R. Chemistry and structure of esseneite $\left(\mathrm{CaFe}^{3+} \mathrm{AlSiO}_{6}\right)$ a new pyroxene produced by pyrometamorphism. Am. Mineral. 1987, 72, 148-156.

24. Sandiford, M.; Neall, F.B.; Powell, R. Metamorphic evolution of aluminous granulites from Labwor Hills, Uganda. Contrib. Mineral. Petrol. 1987, 95, 217-225. [CrossRef]

25. Brotzu, P.; Gomes, C.B.; Melluso, L.; Morbidelli, L.; Norra, V.; Ruberti, E. Petrogenesis of coexisting $\mathrm{SiO}_{2}$-undersaturated to $\mathrm{SiO}_{2}$-oversaturated felsic igneous rocks: The alkaline complex of Itatiaia, southeastern Brazil. Lithos 1997, 40, 133-156. [CrossRef]

26. Markl, G. Mullite-corundum-spinel-cordierite-plagioclase xenoliths in the Skaergaard Marginal Border Group: multi-stage interaction between metasediments and basaltic magma. Contrib. Mineral. Petrol. 2005, 149, 196-215. [CrossRef]

27. Treiman, A.H. Amphibole and hecynite spinel in Shergotty and Zagami: Magmatic water, depth of crystallization, and metasomatism. Meteoritics. 1985, 20, 229-243. [CrossRef]

28. Pardo, G. Estratigrafía y sedimentología de las formaciones detríticas del Cretácico inferior terminal del Bajo Aragón Turolense. Ph.D. Thesis, University of Zaragoza, Zaragoza, Spain, 1979. (In Spanish)

29. Cervera, A.; Pardo, G.; Villena, J. Algunas precisiones litoestratigráficas sobre la Formación "lignitos de Escucha". Tecniterrae 1976, 3, 25-33.

30. Querol, X. Estudio geológico de la Formación Escucha en la Cueca del Maestrazgo, Cordillera Ibérica oriental. Ph.D. Thesis, University of Barcelona, Barcelona, Spain, 1988. (In Spanish)

31. Salas, R. El Malm i el Cretaci inferior entre el Massis de Garraf i la Serra d'Espadà: Anàlisi de conca. Ph.D. Thesis, University of Barcelona, Barcelona, Spain, 1987. (In Catalan)

32. Bauluz, B.; Mayayo, M.J.; Yuste, A.; González López, J.M. Genesis of kaolinite from Albian sedimentary deposits of the Iberian Range (NE Spain): analysis by XRD, SEM and TEM. Clay Miner. 2008, 43, 459-475. [CrossRef]

33. Hillier, S. Quantitative analysis of clay and other minerals in sandstones by X-ray powder diffraction (XRPD). Int. Assoc. Sedimentol. Spec. Publ. 2003, 34, 213-251.

34. Schwartz, K.B.; Leong, D.B.; McConville, R.L. Structural chemistry of synthetic cordierite: Evidence for solid solutions and disordered compositional domains in Bi-flux-grown Mg-cordierites. Phys. Chem. Miner. 1994, 20, 563-574. [CrossRef]

35. Hill, R.J. X-ray powder diffraction profile refinement of synthetic hercynite. Am. Mineral. 1984, 69, 937-942.

36. Johnson, J.S.; Clark, J.; Miller-Antonio, S.; Robins, D.; Schiffer, M.B.; Skibo, J.M. Effects of Firing Temperature on the Fate of Naturally Occurring Organic Matter in Clays. J. Archaeol. Sci. 1988, 15, 403-414. [CrossRef]

37. Aras, A. The change of phase composition in kaolinita- and illite-rich clay-based ceramic bodies. Appl. Clay Sci. 2002, 24, 257-269. [CrossRef]

38. Merriman, R.J.; Peacor, D.R. Very-low grade metapelites: Mineralogy, microfabrics and measuring reaction progress. In Low-Grade Metamorphism, 1st ed.; Frey, M., Robinson, D., Eds.; Blackwell Science: Hoboken, NJ, USA, 1998; pp. 10-60. [CrossRef]

39. Ram, L.C.; Tripathi, P.S.M.; Mishra, S.P. Mössbauer spectroscopic studies on the transformations of iron-bearing minerals during combustion of coals: Correlation with fouling and slagging. Fuel Process. Technol. 1995, 42, 47-60. [CrossRef]

40. Kapička, A.; Petrovsky, E.; Ustjak, S.; Macháčková, K. Proxy mapping of fly-ash pollution of soils around a coal-burning power plant: A case study in the Czech Republic. J. Geochem. Explor. 1999, 66, 291-297. [CrossRef]

41. Floyd, M.; Czerewko, M.A.; Cripps, J.C.; Spears, D.A. Pyrite oxidation in Lower Lias Clay at concrete highway structures affected by thaumasite, Gloucestershire, UK. Cem. Concr. Compos. 2003, 25, 1015-1024. [CrossRef]

42. Ritsema, C.J.; Groenenberg, J.E. Pyrite Oxidation, Carbonate Weathering, and Gypsum Formation in a Drained Potential Acid Sulfate Soil. Soil Sci. Soc. Am. J. 1993, 57, 968-976. [CrossRef] 
43. Estrada, S.; Piepjohn, K.; Frey, M.J.; Reinhardt, L.; Andruleit, H.; Von Gosen, W. Pliocene coal-seam fires on southern Ellesmere Island, Canadian Artic. N. Jb. Geol. Paläont. 2009, 251, 33-52. [CrossRef]

44. Müke, A. Magnetite, ilmenite and ulvite in rocks and ore deposits: petrography, microprobe analyses and genetic implications. In Mineralogy and Petrology, 1st ed.; Nasdala, L., Broekmans, M.A.T.M., Eds.; Spinger: Viena, Austria, 2003; Volume 77, pp. 215-234. [CrossRef]

45. Smith, D.G.W. The chemistry and mineralogy of some emery-like rocks from Sithean Sluaigh, Strachur, Argyllshire. Am. Mineral. 1965, 50, 1982-2022.

46. Stoddar, E.F. Zinc-rich hercynite in high-grade metamorphic rocks: A product of the dehydration of staurolite. Am. Mineral. 1979, 64, 736-741.

47. Ridolfi, F.; Braga, R.; Cesare, B.; Renzulli, A.; Perugini, D.; Del Moro, S. Unravelling the complex interaction between mantle and crustal magmas encoded in the lavas of San Vincenzo (Tuscany, Italy). Part I: Petrography and Thermobarometry. Lithos. 2016, 244, 218-232. [CrossRef]

48. Berg, R. Tungsten skarn mineralizations in a regional metamorphic terrain in northern Norway: A possible metamorphic ore deposit. Miner. Deposita 1991, 26, 281-289. [CrossRef]

49. Trindade, M.J.; Dias, M.I.; Coroado, J.; Rocha, F. Mineralogical transformations of calcareous rich clays with firing: A comparative study between calcite and dolomite rich clays from Algarve, Portugal. Appl. Clay. Sci. 2009, 42, 345-355. [CrossRef]

50. D'Souza, M.; Keshava Prasad, A.V.; Ravindra, R. Genesis of Ferropotassic A-Type Granitoids of Mühlig-Hofmannfjella, Central Dronning Maud Land, East Antarctica. In Antarctica: Contributions to Global Earth Sciences, 1st ed.; Fütterer, D.K., Damaske, D., Kleinschmidt, G., Miller, H., Tessensohn, F., Eds.; Springer: Berlin/Heidelberg Germany, 2006; pp. 45-54. [CrossRef]

51. Huffman, G.P.; Huggins, F.E.; Shah, N. Behavior of basic elements during coal combustion. Prog. Energ. Combust. 1990, 16, 243-251. [CrossRef]

(C) 2019 by the authors. Licensee MDPI, Basel, Switzerland. This article is an open access article distributed under the terms and conditions of the Creative Commons Attribution (CC BY) license (http://creativecommons.org/licenses/by/4.0/). 